\title{
ANALYSIS OF INTERMEDIATE AND POOR PROGNOSTIC GROUP OF PATIENTS WITH METASTATIC KIDNEY CANCER TREATED AT THE UNIVERSITY HOSPITAL CENTER ZAGREB
}

\author{
MARKO BEBEK ${ }^{1}$, MAJA BAUČIĆ ${ }^{1}$, SANJA ŠANDRK ${ }^{1}$, \\ MILENA GNJIDIĆ ${ }^{2}$ and MARIJA GAMULIN ${ }^{2}$ \\ ${ }^{1}$ Department of Oncology, University Hospital Center Zagreb, Zagreb, Croatia; \\ ${ }^{2}$ Division for Medical Oncology, Unit for Uro-Oncology, Department of Oncology, \\ University Hospital Center Zagreb, Zagreb, Croatia
}

\begin{abstract}
SUMMARY
Forty two to $57 \%$ of patients with metastatic renal cell carcinoma (mRCC) receive the second-line therapy according to available data. In our analysis we wanted to determine the percentage of patients within intermediate/poor prognostic group $\mathrm{mRCC}$ who continued the treatment with the second line following progression on the first line and the percentage of patients who were not able to receive the second line treatment. Patients received sunitinib (first started on 12 August 2018) or pazopanib (first started on May 2014) at University Hospital Center Zagreb. The latest treatment started in December 2018 . Our results show that $39.4 \%$ of patients who received sunitinib and $37.9 \%$ of patients who received pazopanib, did not receive the second line treatment, which is consistent with available data. The question arises whether we could have helped those patients if we had access to newer therapeutic options.
\end{abstract}

KEY WORDS: Metastatic kidney cancer, treatment sunitinib, pazopanib

ANALIZA BOLESNIKA S METASTATSKIM RAKOM BUBREGA
SREDNJE I LOŠE PROGNOSTIČKE SKUPINE
LIJEČNIH U KLINIČKOM BOLNIČKOM CENTRU ZAGREB

\section{SAŽETAK}

Prema literaturnim podacima oko $42 \%$ do $57 \%$ bolesnika s metastatskim karcinomom bubrega primi drugu liniju liječenja. Retrospektivnom analizom naših podataka htjeli smo prikazati postotak bolesnika s metastatskim karcinomom bubrega koji pripadaju srednjoj/lošoj prognostičkoj skupini a koji su nastavili liječenje drugom linijom nakon progresije na prvolinijsko liječenje. Također smo htjeli prikazati postotak bolesnika koji nisu bili u mogućnosti nastaviti drugolinijsko liječenje. Bolesnici su primali sunitinib (prvi bolesnik je započeo liječenje u svibnju 2014.) i pazopanib (prvi bolesnik je započeo liječenje 12. kolovoza 2018) u Kliničkom bolničkom centru Zagreb. Uključeni su bili bolesnici koji su liječenje započeli do kraja prosinca 2018. godine. 39.4\% bolesnika koji su primali sunitinib i 37.9\% bolesnika koji su primali pazopanib, nije primilo drugu liniju liječenja, što se podudara s literaturnim podacima. Nameće se pitanje, jesmo li navedenim bolesnicima mogli pomoći da smo imali dostupne novije terapijske opcije.

KLJUČNE RIJEČI: metastatski karcinom bubrega, liječenje, sunitinib, pazopanib 


\section{INTRODUCTION}

Improved understanding of von Hippel-Lindau gene mutations lead to the induction of angiogenic protein and development of vascular endothelial growth factor (VEGF)-targeted therapies with tyrosine kinase inhibitors (TKIs). TKIs sunitinib and pazopanib represent a standard first-line treatment for patients with clear cell metastatic kidney cancer. Since 2009, when pazopanib was approved by the United States Food and Drug Administration (FDA), no other agent has been approved for the first-line therapy setting (1).

Novel targeted therapies, immune checkpoint inhibitors, and immune-modulating drugs with promising results in phase III clinical trials are changing the first-line setting, and they are replacing sunitinib, pazopanib, as preferred firstline agents.

In our analysis, we wanted to determine the proportion of patients with intermediate/poor prognostic group $\mathrm{mRCC}$ who continued the treatment with the second line following progression on the first line and the proportion of patients who were not able to receive the second-line treatment.

\section{MATERIAL AND METHODS}

We analyzed patients who received sunitinib or pazopanib at the University Hospital Center Zagreb as the first-line treatment for mRCC. Firstline therapy was defined as the first administered TKI within the treatment history for $\mathrm{mRCC}$. Second-line therapy was any other systemic therapy after the first-line TKI treatment. Discontinuation of the first-line treatment was due to progressive disease, therapy-limiting toxicity, or the patient's request. Patients were treated with the second-line therapy when eligible according to applicable treatment guidelines and local standards (including ECOG status, and laboratory findings). Progression was defined by radiological evidence of the disease progression according to the Response evaluation criteria in solid tumors (RECIST) criteria, clinical signs of the progression, or death from the disease. Treatment and therapeutic monitoring, based on computed tomographic scans every three months, were applied according to guidelines and local standards. Clinical data were extracted from medical charts and collected in a da- tabase. Physicians assessed data in an anonymized manner following recommendations of the local ethics committee and the Helsinki declaration in its latest revised version.

All patients were divided into subgroups for comparison according to gender, age, ECOG status, nephrectomy or kidney biopsy before introduction of first-line therapy, pathohistological finding of sarcomatoid component, number (less than three or more) and distribution of metastases before the onset of systemic therapy, MSKCC prognostic group (favorable, intermediate/poor), and second-line treatment.

\section{RESULTS}

Patients started to receive sunitinib on $12 \mathrm{Au}$ gust 2008 and pazopanib on 16 May 2014. The latest treatment started in December 2018. Out of 295 patients, 181 received sunitinib, and 114 received pazopanib. One hundred nine patients $(60 \%)$ who received sunitinib and 66 patients who received pazopanib were, according to MSKCC prognostic groups, in the intermediate/poor prognostic group. Twenty-one patients $(19.3 \%)$ are still receiving sunitinib as the first-line therapy, and 16 patients $(24.2 \%)$ are still receiving pazopanib in the first line. A total of 43 patients $(39.4 \%)$ who received sunitinib did not receive the second-line treatment, whereas $45(41.3 \%)$ patients received the second-line treatment as follows: 20 (44.4\%) nivolumab, $10 \%$ axitinib (22.2\%), everolimus 11 $(24.4 \%)$, other therapies 4 (9\%). Twenty-five patients $(37.9 \%)$ who received pazopanib did not receive the second-line treatment, whereas 25 $(37.9 \%)$ patients received the second-line treatment as follows: $12(48 \%)$ nivolumab, axitinib 6 $(24 \%)$, everolimus $6(24 \%)$ other therapies $1(4 \%)$.

\section{DISCUSSION}

Currently, only $42 \%-57 \%$ of patients with $\mathrm{mRCC}$ receive second-line therapy according to previously published data $(2,3)$. Our results are very similar. The reasons for the high dropout rate before patients enter the second-line therapy are largely unknown (4). Death related to rapid tumor progression during first-line therapy does not explain this phenomenon sufficiently (5). 
The question arises whether we could have helped other patients if we had access to other (novel) therapeutic options. It is well known that the combination of TKIs and immunotherapy yields a better response to therapy, and treatment with multiple lines of therapy results in more prolonged overall survival. Optimizing the treatment of mRCC using the combination of immunotherapy and targeted agents, as well as the possible favorable sequence of treatments between these two classes of drugs, remains an open question at this moment.

Another critical question that arises from better results from each clinical trial is: Can we afford it? Rising expenses of such therapies can act as a barrier for many patients. The cost of immunotherapy for $\mathrm{mRCC}$ is following the same trend of most new drugs and biologics. The economic burden of mRCC treatment is growing with the increasing use of targeted therapies, and we urgently need reliable biomarkers of tumor response. The results obtained in recent years have raised enormous enthusiasm in cancer researchers, aimed at identifying, isolating, and validating biomarkers associated with the dynamics of the tumor environment and the therapeutic response. However, we are still waiting for the implementation of these results into everyday clinical practice.

\section{CONCLUSION}

The proportion of patients who were not able to receive the second-line treatment in our study is in accordance with the previously published data. A combination of TKIs and immunotherapy showed better response to therapy, and the treatment with multiple lines of therapy results in more prolonged overall survival. Although still unavailable because of the high economic burden and lack of predictive biomarkers, we hope that mRCC patients will soon have an opportunity for more effective novel treatments in the Republic of Croatia.

\section{REFERENCES}

1. Santoni M, Massari F, Di Nunno V, Conti A, Cimadamore A, Scarpelli M, Lopez-Beltran A et al. Immunotherapy in renal cell carcinoma: latest evidence and clinical implications. Drugs Context. 2018;7:212-528.

2. Motzer RJ, Barrios CH, Kim TM, Falcon S, Cosgriff T, Harker WG, et al. Phase II randomized trial comparing sequential first-line everolimus and second-line sunitinib versus first-line sunitinib and second-line everolimus in patients with metastatic renal cell carcinoma. J Clin Oncol. 2014 Jan 9;32(25):2765-72.

3. Eichelberg C, Vervenne WL, De Santis M, Fischer von Weikersthal L, Goebell PJ, Lerchenmüller C, et al. SWITCH: A randomised, sequential, open-label study to evaluate the efficacy and safety of sorafenib-sunitinib versus sunitinib-sorafenib in the treatment of metastatic renal cell cancer. Eur Urol. 2015;68(5): 837-47.

4. Eggers H, Ivanyi P, Hornig M, Grünwald V. Predictive Factors for Second-Line Therapy in Metastatic Renal Cell Carcinoma: A Retrospective Analysis. J Kidney Cancer VHL. 2017;4(1):8-15.

5. Alimohamed N, Lee J-L, Srinivas S, Bjarnason GA, Knox JJ, Mackenzie MJ, et al. A population-based overview of sequences of targeted therapy in metastatic renal cell carcinoma. Clin Genitourin Cancer. 2014;12(4):e127-131.

Corresponding author: Marko Bebek, Department of Oncology, University Hospital Center Zagreb, Kišpatićeva 12, 10000 Zagreb, Croatia.e-mail: marko.bebek.zg@gmail.com 